\title{
Does US Foreign Aid Undermine Human Rights? The "Thaksinification" of the War on Terror Discourses and the Human Rights Crisis in Thailand, 2001 to 2006
}

\author{
Salvador Santino Fulo Regilme $\mathbf{J r}^{1}$
}

Published online: 7 December 2017

(C) The Author(s) 2017. This article is an open access publication

\begin{abstract}
What is the relationship between Thailand's human rights crisis during Prime Minister Thaksin Shinawatra's leadership (2001-2006) and the USA-led post-9/11 war on terror? Why did the human rights situation dramatically deteriorate after the Thaksin regime publicly supported the Bush administration's war on terror and consequently received US counterterror assistance? This article offers two conceptual arguments that jointly demonstrate a constitutive theoretical explanation, which shows that counterterror and militaristic transnational and national discursive structures enabled the strategy of state repression in Thailand under Thaksin. The first concept refers to strategic localization, which refers to how the Bush administration's global war on terror-and its consequent overarching emphasis on military security-provided an opportunity for the Thaksin administration to strategically localize the global threat of terrorism in ways that could seem relevant to the local Thai context. The second concept pertains to resource mobilization, which shows how converging US and Thai discourses on military security facilitated Thaksin's strategy of increased state repression that led to the proliferation of state-led human rights abuses. This research article contributes to the human rights literature in two ways: (1) by highlighting how foreign aid programs and its constitutive political discourses shape recipient countries' domestic human rights situation (2) and by tracing the macropolitical factors that lead to the eventual democratic decay of contemporary Thailand.
\end{abstract}

Salvador Santino Fulo Regilme, Jr s.s.regilme@hum.leidenuniv.nl

1 History and International Studies, Institute for History, Leiden University, Leiden, The Netherlands 


\section{Introduction}

Thailand nowadays is arguably one of the most politically unstable countries in Southeast Asia. Once dubbed as one of the only two electoral democracies in the region (the other is the Philippines), ${ }^{1}$ Thailand, since late 2006, has been experiencing a series of political challenges, particularly because of military coups, national political scandals of corruption, and the current military junta. During the term of Prime Minister Thaksin Shinawatra (2001-2006), Thailand's human rights situation began to decay in ways that directly undermined the liberal constitutional reforms and democratic institutional gains in the 1990s. Thus, Thailand under Thaksin's leadership underwent an early phase of democratic decay since the restoration of electoral democracy in the 1990s. In contrast to the 1990s when state-sanctioned extrajudicial killings and disappearances rarely occurred, Thailand, under Thaksin's leadership, experienced a much more widespread and systematic implementation of state-inflicted human rights violations. Specifically, the number of state-initiated human rights abuses dramatically increased after 2003, when the Thaksin-led Thai government publicly supported the USA-led War on Terror. Particularly, the Thai government discursively framed the USA-led global war on terror as the effective strategy in resolving Thailand's long-standing internal security threats. Consequently, the implementation of USA-supported counterterrorism in Thailand fueled Thaksin's efforts in consolidating his power as well as in entrenching his own Thai Rak Thai political party in the upper echelons of state leadership.

Notably, Thaksin's government implemented violent crackdown on suspected drug addicts and large-scale implementation of counterterror operations against Islamic and secessionist rebels. For instance, the post-9/11 Thaksin-led government reported 1300 cases of state-led killings during the "War on Drugs" in 2003 alone, while the Human Rights Watch claimed that the number could have been as high as 2500 . Local media outlets in Thailand reported that the "three-month climate of fear resulted in 58,000 arrests, 2,274 deaths, and surrenders to authorities by more than 42,000 alleged drug traffickers" (Mutebi 2004, 80) Besides, Thai police officers and other armed forces members killed around 4,700 civilians in the southern provinces from 2004 to 2006 when counterterror operations were officially launched against the armed Islamic insurgents. As the Thai government implemented the USA-funded "War on Drugs," the country fell from 59th place in 2004 to 107th out of 167 states in 2005 in the Press Freedom Index of the Reporters without Borders. The proliferation of state-initiated abuses during the term of Thaksin is widely considered as the worst human rights record in Thailand's recent political history. Figure 1, for example, illustrates the substantial increase in the severity of state repression and human rights violations in the 2000s, when compared to the levels recorded in the 1990s.

Similarly, the combined amounts of US bilateral aid to Thailand increased in the 2000s, at levels much higher than those recorded in the 1990s (refer to Fig. 2). Particularly, the amount of US military and economic aid to Thailand doubled from the annual average of 22.5 million USD for the period of 1993 to 2001 to 50.3 million USD for the period of 2002 to 2009. Specifically, the total amount of US aid from 1993 to 2001 was only 202 million USD, an amount that was much lower compared to 403 million USD that Thailand received from the USA for the years 2002 to 2009 . Whereas US aid in the 1990s was allocated to a much wider

\footnotetext{
${ }^{1}$ Refer to Regilme (2016) for further discussion on democratization challenges in Asia, particularly the Philippines.
} 


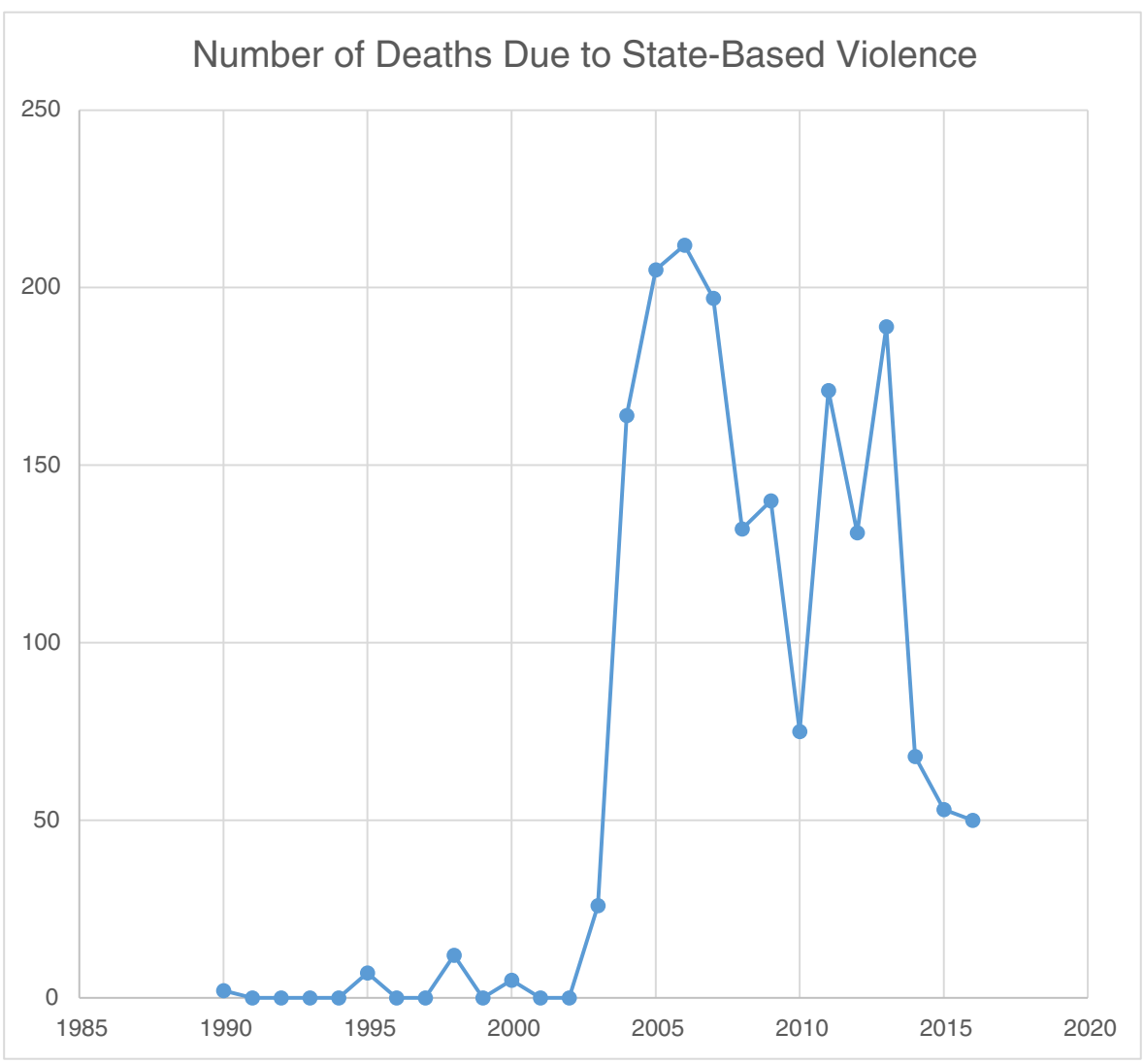

Fig. 1 Uppsala Conflict Database Program — data for Thailand, state-initiated incidents of civilian death from 1989 to 2014; source: http://ucdp.uu.se/

range of militaristic and non-militaristic goals including stronger human rights protection and democracy promotion, US bilateral assistance for the years 2001 to 2004 was primarily geared towards Thailand's own domestic counter-insurgency efforts and the arbitrary policy decisions of Thaksin and his political party.

The deterioration of the human rights situation that started in 2003 apparently correlated with the increase of US bilateral aid to Thailand that started in the early 2000s when the Thai government joined the Bush administration's global war on terror. Thus, this article provides preliminary evidence and conceptual arguments in response to this main puzzle: Did counterterror US foreign aid and political discourses facilitate increased state repression in Thailand under Prime Minister Thaksin Shinawatra (2001 to 2006)? If so, how and under which set of contextual and discursive conditions did such a strategic assistance program lead to a human rights crisis in Thailand?

While it is very hard to pin down direct causal relationship between US aid and the human rights crisis in Thailand under Thaksin's regime, this article demonstrates how those two variables, at the very least, coincided during the same period, and it offers some tentative and preliminary arguments about their relationship. As I argue in this article, the terror-oriented political discourses and the military assistance of the USA under the Bush administration facilitated the ambitious expansion of the Thai state's coercive capacities 


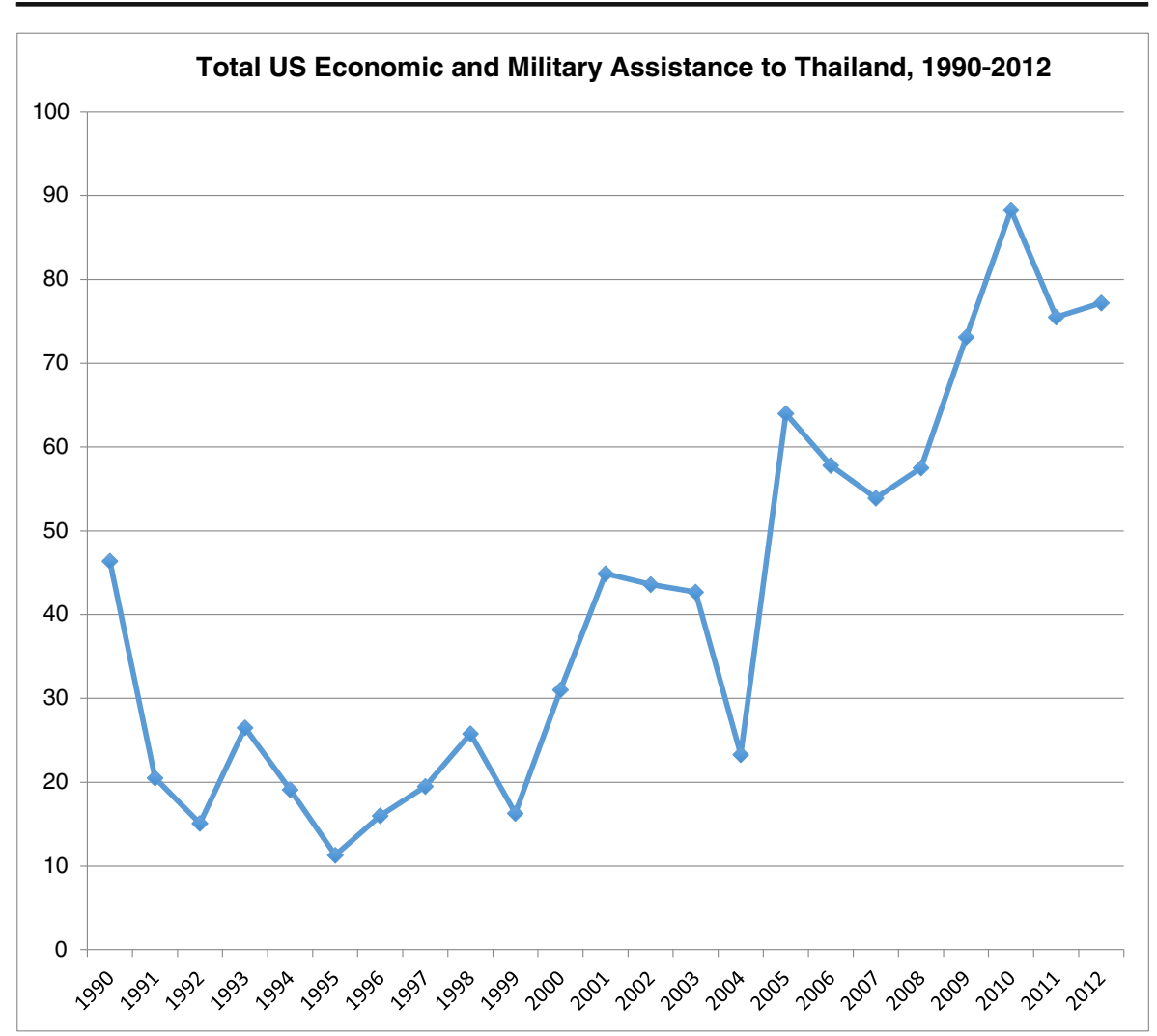

Fig. 2 Total US economic and military aid to Thailand, 1990-2012 (in millions USD). Source: USAID GREENBOOK, https://www.usaid.gov/developer/greenbookapi

that were crucial in increased state repression under the Thaksin regime. The American counterterror support for Thaksin's government is a case study that demonstrates how less powerful states still require external political support for regime consolidation. In periods of transnational security crises, the tactical counterterror alliance between powerful states and its dependent state allies could inadvertently undermine international human rights norms.

Hence, this article, demonstrates two key patterns of post-9/11 relationship between the USA and Thailand, with a particular focus on the political discourses and the ideational aspects that constitute their diplomatic relations and bilateral cooperation. First, the Thaksin government's political and policy discourses reframed the USA-funded global war on terror in ways that facilitated the influx of US counterterror assistance, which in turn, would consolidate the rule of Thaksin over the Thai state's coercive and noncoercive apparatuses. Second, those counterterror political discourses sought to legitimize the dramatic restructuring of resources within the Thai state, by primarily reorienting its agencies towards a counterterror and coercive focus, thereby empowering the military and police forces in ways that were unprecedented since the 1990s.

This research article contributes to the human rights literature in three ways: (1) by highlighting the plausible role of international factors (such as foreign aid and its constitutive political discourses) into the domestic politics of state repression and human rights abuses, (2) by tracing the initial macro-political factors that led to the 
eventual democratic decay of contemporary Thailand, and by (3) highlighting the role of discourses and ideas in examining the impact of foreign aid.

Thus, this article is organized as follows. The next section briefly reviews the relevant literature on human rights and its relationship to foreign aid, and that part presents the theoretical arguments that underpin this case study of Thailand. Next, I analyze the key similarities and the variations in US and Thai governments' counterterror discourses. It particularly focuses on the Thaksin-led government's strategic ideational association of the global armed extremist Islamic movement with the longstanding illegal drug use and trafficking problem as well as non-state armed threat in Thailand. Consequently, the article examines how those strategically reframed discourses facilitated the reorientation of the Thai state's material resources as well as external aid to Thailand from a primarily non-militaristic focus to a counterterror orientation - an outcome that resulted to the increase in state repression and incidents of state-led human rights abuses. Theoretically, those two patterns demonstrate how political discourses and macro-political actions of state agents constitute each other, thereby creating transformative political changes, including a human rights crisis under the Thaksin regime.

\section{What We Know So Far: Foreign Aid and Human Rights in the Literature}

Human rights and foreign aid are not only important concepts that occupy a central role in academic scholarship but they are also influential in the actual practice of international politics. For many human rights victims, especially those in countries that usually receive large amounts of foreign aid from Western countries, we need to know whether such an external assistance program has a causal relationship at all with their state's repressive practices. ${ }^{2}$ For some donor countries, most especially the USA, it is all the more compelling to investigate whether or not the financial assistance that they provide to other countries really produce its intended outcomes. ${ }^{3}$ To be sure, one of those envisioned outcomes of foreign assistance, at least for the USA, is stronger human rights protection in aid recipient countries - a policy goal that even became more important since the end of the Cold War (Meernik et al. 1998; Cingranelli and Richards 1999). Each year, thousands if not millions of human lives suffer or die because of the abuses committed by government agents, who are, in fact, expected to honor the human rights commitments of the state. Thus, investigating the causal relationship between foreign strategic support or assistance and the human rights situation in recipient countries merit a systematic investigation.

Notably, the scholarly literature addressing the causal relationship between foreign aid and human rights outcomes in recipient countries has not been fully settled. Some recent studies suggest that donor countries influence foreign aid decisions (HafnerBurton 2014, 278-279; Demirel-Pegg and Moskowitz 2009). Interestingly, however, some recent studies show that the US government regularly provides economic assistance to recipient governments that implement high levels of state repression (Lai 2003; Lebovic 1988; Cingranelli and Pasquarello 1985; Petras 1997). A more interesting and

\footnotetext{
${ }^{2}$ See Robinson (1996).

3 The USA is the world's biggest giver of foreign assistance, providing much heftier amounts of aid than the next runners-up, Germany and France. (Debusman 2011).
} 
compelling question, nonetheless, is whether or not foreign strategic support impacts the severity and pervasiveness of state-initiated human rights abuses in recipient countries. On that regard, the scholarly literature is undecided regarding this purported direction of causal relationship. As Emilie Hafner-Burton $(2014,279)$ rightly contends, "the precise effects of foreign aid or its conditionality on human rights" are still unknown, primarily because "most research has explored the effects of aid on development, or more broadly, good governance." Indeed, results regarding the relationship between aid and human rights are inconclusive. Whereas a recent study points out that aid from the European Union strengthens human rights protection (Carnegie and Marinov 2017), there are several studies, which suggest that US aid can undermine human rights (Lee 2011; Sikkink 2004).

Employing a systematic, cross-national, and quantitative study of human rights, Choi and James (2017) suggest a more pessimistic view of US foreign policy, including its aid programs. Particularly, Choi and James $(2017,340)$ propose the Hegemonic Intervention Hypothesis, which refers to the consequences of US foreign policy actions and maintains that "regardless of whether the foreign policy tool is economic or military, the impact of the leading state's intervention on human rights is anticipated to be neutral, if not harmful." This pattern of US foreign aid's detrimental impact on human rights confirms that aid can bolster the resources needed for state repression which, in turn, could embolden the political resolve of recipient government's leaders (Kono and Montinola 2009). Consequently, those resources could empower the recipient government in consolidating its power through the violent repression of all forms of political opposition - even the unarmed ones, thereby undermining its human rights obligations. For example, based on the quantitative evidence from US military aid to Colombia, Dube and Naidu $(2015,249)$ find that "foreign military assistance may strengthen armed nonstate actors, undermining domestic political institutions." Such a pattern happened when Colombian military forces diverted US aid to illicit paramilitary non-state groups, an outcome that intensified political violence and inadvertent killings of civilians.

Meanwhile, the detrimental impact of foreign aid can be attributed to its fungible nature. Consequently, such an inherent nature of foreign aid emboldens leaders of recipient government leaders to use those external resources for unintended goals such as increased violent political repression of all forms of political dissent (Qian 2015, 2728).

In short, the relationship between US foreign policy (foreign aid and public diplomacy) and recipient countries' human rights outcomes is a puzzle that has just recently gained traction in mainstream empirical social science scholarship. Focusing on post-9/ 11 USA-Thailand bilateral relations, this paper focuses on the following puzzle: why did the human rights situation dramatically deteriorate after the Thaksin regime publicly supported the USA-led war on terror and consequently received US counterterror assistance? How and to what extent did post-9/11 US counterterror discourses shape Thaksin's policy agenda on increased state repression?

Departing from the recent social literature on foreign aid and human rights that primarily focuses on aid as a material resources, the case study on Thailand highlights the role of political discourses and ideas that shape recipient government's use of their own domestic resources and foreign assistance. That shift to discourses, or non-material aspects of foreign policy, is important precisely because much of the empirical- 
quantitative literature on this topic has thus far only focused on aid as a material resource. Yet, an often disregarded but important assumption is that the outcome of any material political resource also depends on the strategic intentions and ideas of the political actors. As the Berlin-based International Relations scholar Thomas Risse argues, "socially shared ideas-be it norms ("collective expectations about proper10behavior for a given identity') or social knowledge about cause-and-effect relationships - not only regulate behavior but also constitute the identity of actors" (Risse 2000, 5). In this case, examining the impact of the USA on human rights outcomes in partner countries requires a closer look into the discourses of both the donor and recipient governments. That is because publicly articulated political discourses, policy diagnoses, and political beliefs illustrate relevant stakeholders' intentions in regard to the aims, justifications, and implementation goals of foreign aid programs.

The next section builds the theoretical groundwork needed for the empirical analysis of the human rights crisis in post-9/11 Thailand. Particularly, I introduce the concepts of strategic localization and resource allocation in the next section.

\section{Theorizing Aid: Strategic Localization and Resource Mobilization}

Responding to the question of whether counterterror US foreign aid and political discourses led to the human rights crisis in Thailand in the early 2000s, I offer two preliminary arguments. The first contention refers to an important relationship between terror-oriented post-9/11 US foreign policy, which includes its aid programs and public diplomacy, and military security-driven policy agenda of Thaksin. Thus, the Bush administration's global war on terror - and its consequent overarching emphasis on military security - provided an opportunity for the Thaksin administration to strategically localize the global threat of terrorism in ways that could seem relevant to the local Thai context. Facilitated by the discursive ambiguity of global and transnational policy agendas, strategic localization enables local political actors to repackage, to reframe, and to reinterpret transnational/global discourses, beliefs, and norms in ways that effectively resonates with the targeted local audiences. Yet, that ideational process is highly politicized, for localization aims to legitimize the partially converging interests of aid donor and recipient governments. Also, through strategic localization, domestic political actors intend to convince their public constituencies that a shift in general policy strategy is warranted (e.g., shift in democratization reforms in the 1990s to military security in the post-9/11 era). Consequently, this ideational process of strategic localization enables the domestic political actors in aid recipient counties to enhance their political legitimacy as well as to provide normative justifications to sudden and transformative policy agendas. Notably, similar to the notion of "securitization of foreign aid" (Brown and Grävingholt 2016), my notion of strategic localization goes beyond traditional military security concerns because it includes a wide range of substantive policy concerns, by which the specific combination could vary depending on the donor and recipient governments at a given point in time.

The second argument pertains to the constitutive link between ideational discourses and the tangible material consequences that occur in the policy realm. Particularly, I make the case that the post-9/11 US and Thai governments' converging discourses on 
military security provided the impetus to allocate domestic state resources and US foreign aid in ways that bolstered the institutional capacities and political importance of the Thai state's coercive apparatus. Hence, resource mobilization refers to the process of setting priorities over the use of internal/domestic state resources as well as foreign aid. That process of resource allocation does not occur without any explicit political strategy. Through strategic localization, political actors seek to justify the substantial changes in the allocation of resources in state-making. When military security is invoked as the overarching state agenda (e.g., Cold War or after the 9/11 attacks), the central government prioritizes the resource needs of and provides special attention to its coercive state agencies - particularly the military, police, intelligence agencies, among others. Considering that military security-centered agenda, the central government relegates other non-militaristic policy portfolios at a low level of priority. In the absence of a military security crisis or a state security threat, the central civilian government allocates its own domestic resources and foreign aid on a fairly diffuse way across a wide range of militaristic and non-militaristic policy portfolios of the state. In other words, resource mobilization refers to the recipient government's over-all prioritization strategy in the allocation of foreign aid and its own domestic resources, ranging from a diffused range of policy priorities to a militaristic, terror-oriented agenda.

At a higher level of abstraction, my explanation for the human rights crisis in Thailand under Thaksin's leadership should be considered as a primarily constitutive theoretical endeavor. Alexander Wendt $(1998,105)$ considers constitutive theories to have a distinctive goal, which is to consider the "properties of things by reference to the structures in virtue of which they exist" - or, more precisely, it is "an effort to explain how systems are constituted." Hence, my goal herein is not to make a stringent causal explanation that directly links US foreign assistance with the human rights crisis in Thailand. Instead, I offer "explanations by concept" (Wendt 1998, 111). In particular, strategic localization and resource mobilization function as analytic concepts that describe the processes through which US and Thai political actors legitimized and actively implemented intensified state repression as an overarching policy goal. That local strategy in Thailand emerged amidst the counterterror-oriented global governance agenda that gained traction in the early years after the 9/11 attacks. That emerging counterterror agenda represents the structural realm of possibilities for key transnational and local political actors. Wendt $(1992,405)$ maintains that those discursive structures "create expectations on both sides [local and transnational] about each other's future behavior," and they motivate "actors for holding certain ideas about each other and discourages them from holding others." During the immediate years following the 9/11 attacks, discursive structures focused on militaristic and counterterror responses that both the US and the Thai governments imbibed. The following sections of this article demonstrate the converging counterterror agendas of the Bush and Thaksin and administrations and the intensified state repression that followed thereafter.

\section{US Foreign Policy Discourses and Bangkok's Localization of the Post-9/11 Threat}

The Thai government's participation in the USA-led War on Terror began through careful and widespread use of various rhetorical strategies that sought to justify a terror- 
oriented policy agenda. Compared to the Philippine government that immediately offered unconditional support to the Bush administration, just right after the 9/11 attacks, the Thaksin-led administration delayed its public support to the US government. It was only in 2003, during the official state visit of Thaksin to the White House, the Thai government publicly and almost unequivocally supported the Bush administration's War on Terror. Yet, the increased US counterterror aid to Thailand and other forms of increased bilateral cooperation on the counterterror front began as early as December 2001, thereby preceding the public expression of political support in 2003. Prior to 2003, the "low-key approach to terrorism" of Prime Minister Thaksin Shinawatra "was partly attributable to fear of frightening away the tourist trade, inciting Thai Muslims against him, and provoking an Al-Qaeda-like attack" (Chambers 2004, 468).

The Bush administration attempted to legitimize this militaristic approach by invoking the long-standing and special relationship of the USA with Thailand. By intensively promoting Thailand as a key non-NATO ally of the USA, Bush also conferred various non-material benefits to Thaksin's government and the Royal Thai Armed Forces. Because Thaksin's Thai Rak Thai (TRT) party's political support base was primarily limited to the rural regions, the Thaksin regime considered that the intensification of USThai security cooperation would likely result in the emergence of stronger support from the once critical Thai monarchy and other political elites. Except for Thaksin's TRT party, many members of the establishment elites, including the monarchy and highranking bureaucrats, "see the United States as a relatively benign and stabilizing power," a belief that is "close to axiomatic in foreign policy circles" in Bangkok (Hamilton-Hart 2012, 2). That is why Thaksin and the TRT party, notwithstanding its nationalist and pro-rural Thailand rhetoric, fostered a militaristic cooperation with the US government in order to appease these influential and traditionally pro-US elites based in Bangkok. Thaksin's justification for Thailand's role in the global counterterror effort was much more restrained. In particular, Thaksin initially resorted to economic justifications in order to secure the support of the broader Thai public as well as Bangkok's elites. As the Thai political scientist Chookiat Panaspornprasit keenly observed, "the main political strategies of the coalition government led by the Thai Rak Thai (TRT) during the first two years of the Thaksin administration (2001-2002) have evidently included both the neutralization of domestic challenges and the consolidation of Thaksin's political power base within the Thai polity" (Panaspornprasit 2004, 258).

By providing military aid and other forms of counterterror assistance to Thailand, Bush discarded the historically dismal human rights record of the Thai armed forces. Instead, Bush highlighted the US government's reengagement with the Thai armed forces in terms of its pragmatic value to international counterterror efforts. Bush remarked the following statements during a 2003 press conference with Thaksin in the White House (Associated Press 2003; Bush 2003):

Thailand pledged to fight the war on terror and that pledge is being honored in full...We're confident in the strength of our alliance and I have acted to designate Thailand a major non-NATO ally of the United States. And we're confident in the character of those who defend us. American and Thai forces serve together and train together and study at military academies in each other's countries. 
In response, Prime Minister Thaksin Shinawatra stated that Thailand's designation as a major non-NATO ally of the USA signaled that the "military relations" between the two countries "will be more convenient" (Acharya 2003; Associated Press 2003). Such a statement alluded to several important benefits to Thailand: access to USAmade weapons and funding for various counterterror exercises and training opportunities between the two countries' armed forces agencies. Consequently, the designation of Thailand as a "major non-NATO ally" boosted the Thaksin-led government's domestic authority and amplified the importance of a bilateral military cooperation with the US government.

The Thai government's participation in the USA-led War on Terror took shape in two ways: (1) quelling the armed Islamic insurgency in the southern province and (2) addressing the threat of illegal drug trafficking and other forms of social ills that included political opposition members. The first tactic referred to the belief that the main targets of state repression should be the armed Islamic rebels in the southern provinces, many of which were perceived as linked to Al Jemmayah Al Islamiyah. Second, during the post-9/11 period, the Thai government reframed and redefined the scope of violent state repression. With the aim of entrenching the long-term dominance of the TRT political party and his personal political authority over the state apparatus, Thaksin considered some types of unarmed civilians as "undesirable" members of the Thai society. Accordingly, those "undesirable civilians" became targets of killings, detentions, torture, and other forms of physical harassment. These categories of "unarmed civilians" included suspected drug traffickers, prostitutes, activists, and other political opposition members in the rural provinces. Using the power of words to castigate unarmed civilians, Thaksin branded them as "dark influences" who are suffering from endemic "social ills" (Dabhoiwala 2003; Kuhonta and Mutebi 2006; Mutebi 2004).

This localization of the global war on terror into the Thai war on drugs was a product of converging interests and policy preferences of the Bush and Thaksin administrations. In fact, as early as December 2001, President Bush explicitly linked international terrorism to illegal drug trafficking (Associated Press 2001): "If you quit drugs, you join the fight against terrorism...And abroad, it's important for Americans to know that trafficking of drugs finances the world of terror, sustaining terrorists [emphasis mine]." Similarly, the Thai government emphasized illegal drug use and trafficking as the most compelling national security concern. For instance, as one of the most influential figures in the Thai national security establishment, retired general Teerawat Putamanonda told Thaksin during a national security meeting (a month before Thaksin's state visit to the USA): "assistance from the US is necessary to combat narcotics. We have to think seriously about how to maintain such [a] help" (The Nation - Thailand 2001). Because the US and Thai authorities recognized the "huge increase in use of methamphetamine stimulant tablets which Thais call yaa baa or crazy pills smuggled in from neighboring Burma" since the late 1990s, even the influential Thai King Bhumibol Adulyadej was seriously concerned of the problem and therefore "called on the government to take action" without compromising basic rights (Adams 2003, 1). Using the US war on terror as a pretext, Thaksin, at a meeting with other high-ranking government officials on mid-January 2003, "spoke of the necessity to eradicate drug traffickers as a matter of national security" (Connors 2011, 209). These terror-oriented coordinative discourses among Thai government officials and 
political elites exhibited international counterterror discourses being strategically localized into the Thai context, particularly by linking those discourses to domestic security concerns such as illegal drug trafficking.

Although the US State Department criticized Thaksin's 2003 War on Drugs on its annual human rights report, the White House refrained from directly criticizing Thaksin and the Thai armed forces. Just right after the 2003 War on Drugs that led to at least a thousand civilian lives, Thaksin made an official state visit to the White House in June 2003. During this visit, "President Bush did not publicly mention extra-judicial killings, instead praising the campaign's success," and it momentarily appeared in international media that the US government was "willing to ignore Thailand's human rights record in return for closer cooperation against terrorism and Iraq" (Chambers 2004, 472). Bush referred to the war on drugs as Thailand's version of an effective counterterror strategy, thereby contending that Thailand's connection to Southeast Asian Islamic terrorism was strongly linked to illegal drugs. That claim gained traction amidst the lack of convincing evidence that illegal drugs and terrorism were directly linked. Besides, Bush even praised Thailand as a regional example in the War on Terror in Southeast Asia, whereby he referred to "the enhanced cooperation among ASEAN nations that has helped disrupt terror plots" and the apprehension of "members of the Jemaah Islamiyah (JI) terrorist network" (The White House - Office of the Press Secretary 2003). During the 2003 annual Asia-Pacific Economic Cooperation (APEC) summit held in Bangkok, Bush commended the Thai government for its efforts on the war on drugs (Chambers 2004, 467).

Despite the US President Bush's political support for Thaksin, various transnational and domestic civil society networks demanded for the White House to pressure Thaksin to comply with human rights norms. In response, shortly after Thaksin's state visit to the USA, the White House sent in 2003, "an official letter of reproach" that demanded an explanation for the killings (Chambers 2004, 472). Although the letter cited the US Leahy Amendment that could potentially undercut funding to Thai security forces due to its human rights abuses, US military aid was only cut shortly after the military coup in 2006, when Thaksin was already removed from power. Moreover, US pressures for Thailand to comply with its human rights commitments were only channeled through the US Embassy in Bangkok in order not to undermine public support for Thailand's counter-insurgency operations funded by US aid (Montlake 2002; Simon 2003).

With the political support and financial aid from the Bush administration, Thaksin launched two types of counter-insurgency operations. The first referred to the war on "several intractable social ills" (Mutebi 2004). On the 28th January 2003, Thaksin ratified a law that provided detailed guidelines on leading a "concerted effort of the nation to overcome drugs" (Mutebi 2004, 80). Although it only specified guidelines that primarily dealt only with non-violent approaches, including educational programs and public awareness campaigns against illegal drugs, the law that authorized the war on drugs in 2003 suggested a much more ambitious goal (Shinawatra 2003): "To quickly, consistently and permanently eradicate the spread of narcotic drugs and to overcome narcotic problems, which threaten the nation." In practice, the law permitted Thaksin's government to empower all police officers and soldiers to efficiently kill all suspected illegal drug users and traffickers by motivating them through attractive financial compensation: "At three baht [US \$0.07] per methamphetamine tablet seized, a government official can become a millionaire by upholding the law, instead of 
begging for kickbacks from the scum of society" (Dabhoiwala 2003; Human Rights Watch 2004a, b, 50). In justifying the war on drugs, Thaksin characterized all unarmed civilians involved in drug trafficking and use as having "intractable social ills."

The second phase of Thaksin's war on terror was locally called the "war on dark influences" (เป็นอิทธิพลมืด). On the 21st May 2003, the Thai government officially declared that a joint police-military campaign would be launched against "some 15 types of criminal activity: the drug trade, influence peddling to fix outcome of bidding contests, extortion at factories, illegal control of motorcycle taxis and other vehicles for hire, oil and goods smuggling, gambling dens and underground lottery rackets, trafficking in women and children, job scams, smuggling of laborers, tourism scams, hired gunmen, forced debt collection, illegal arms trade, and illegal encroachment on public land" (Mutebi 2004, 81). Strangely enough, Thaksin made frequent travels within the country throughout the period of this campaign against "dark influences," while promising rural Thai citizens a "country safe from "corruption, flooding, drought, poverty, drugs, and other 'dark forces"” (Mutebi 2004, 81).

Consequently, Thaksin discarded all the human rights reforms introduced in the 1990s and vigorously "called for law enforcement to be conducted on the basis of an 'eye for an eye'." (Adams 2003, 1). A few months before the official launch of the 2003 War on Drugs, Thailand's Interior Minister Wan warned anybody who is involved in illegal drugs, regardless of their nature of engagement, that "they will be put behind bars or even vanish without a trace. Who cares? They are destroying our country" (Adams 2003, 1). In making the case for the war on drugs, the Thai government characterized illegal drug use and trafficking as the root cause of all other peripheral problems, such as "armed insurgency near border areas, illegal arms trade, vehicle stealing, illegal labour trade, terrorism, and transnational organized crime" (Office of the Narcotics Control Board, Justice Ministry of Thailand 2003; Office of the Narcotics Control Board, Justice Ministry of Thailand 2003, 30). These statements showed how the Thai government strategically persuaded the Thai public by reinforcing two substantive claims: (1) anybody who is involved in illegal drugs deserves to be killed or quickly eliminated by the state and that (2) the drug problem in the country is directly linked to terrorism and other problems that destabilize national security.

Several Thai government officials used various excuses when they faced criticisms pertaining to their abusive use of state repression. For instance, Thai Police Commissioner General Sant Suranont contended that the "police would only fire in selfdefense" (Mutebi 2004, 80). Emphasizing the severity of the problem, Thai Defense Minister Thamarak Isarankula persistently defended the killings: "some three million people are methamphetamine-abusers, 5 per cent of the population. If we allow the situation to continue, we may end up a nation of crazy people" (The Nation - Thailand 2003). In the face of the criticisms from the UN of Thaksin's human rights record, a Thai foreign ministry spokesperson declared to the media that "We want the international community to see our side of the story. It's necessary for the government to take decisive action to deal with the drug problem" (Dabhoiwala 2003). In response, Thaksin derisively asserted that "the United Nations is not my father" (Dabhoiwala 2003). Apparently demonstrative of his commitment to counter-insurgency operations in order to gain the respect of Thai elites and the US government, Thaksin urged his critics to be more reasonable: "Just imagine terrorists bombing the houses of people who oppose the decrees and let's see what they make of that... The government has 
issued the laws constitutionally" (Asian Tribune 2003). Furthermore, in an attempt to temporarily satisfy his critics, Thaksin established two independent committees that sought to ensure that the rule of law would be observed during counter-insurgency operations (Cheesman 2003). Thaksin warned that "critics of the campaign should now direct their empathy to our children who are victims of the drug menace, instead of sounding the alarm for falling traffickers" (Cheesman 2003). In an absurd way of defending his government's methods, Thaksin justified that "summary execution is not an unusual fate for wicked people"(Phongpaichit 2004, 81).

Thaksin and his allies were willing to bypass the pro-human rights reforms that the previous governments in the 1990s introduced. The Thaksin government framed increased state repression as necessary for efficiently wiping out all forms of "social ills," which included armed rebels, ordinary drug traffickers, and political opposition members. In the words of Thai specialist Paul Chambers $(2004,464)$, the post-9/11 Thai government "de-emphasized human rights and democratization, and that led to the adoption of a 'business-driven' and 'pragmatism-over-ideology' approach that seemed characteristic of a corporate CEO." This sense of political pragmatism was translated into state-initiated extrajudicial killings and disappearances of suspected criminals and drug addicts, many of which were just ordinary opposition activists. Towards the end of the three-phase, ten-month war on drugs, Thaksin proudly remarked that the campaign was a clear success and justified again its core purpose: "to maintain the strong communities and the strength of the people for the sustainability in overcoming the drug problem in every area throughout the country" (Human Rights Watch 2004b).

The Thaksin administration usually ignored the criticisms from established political figures. For instance, the government's human rights body, an agency established in the 1990s, strongly criticized the Thaksin administration for its human rights abuses during the "war on drugs" and the "war on dark influences." Right after the two "wars" launched by Thaksin, Pradit Chareonthaitawee, the chief of Thailand's National Human Rights Commission (NHRC), contended that the Thai government indeed planned and implemented widespread human rights abuses and claimed that, as a consequence thereof, "people are living in fear all over the kingdom" (Adams 2003). Pradit also wrote highly critical reports of Thaksin's counter-insurgency operations to the UN Commissioner for Human Rights (UNHCR) in February 2003. In response, Thaksin called Pradit as "ugly" and "sickening." Pradit faced serious threats of impeachment from Thaksin's Thai Rak Thai political party as well as anonymous phone calls from Thaksin's staff who warned Pradit to "stop speaking to the United Nations or die" (Human Rights Watch 2004b). Perhaps one of the most prominent critics of Thaksin's repressive policies was Chuan Leekpai - the leader of the Democrat Party and the longstanding Prime Minister who spearheaded the pro-human rights reforms in the 1990s. He reminded Thaksin that (Connors 2011, 112): "It is true that in some cases...people have disgust towards drug traffickers because they are a source of much evil in society, but there is no exception to allow arbitrary processes above the law." Similarly, the UN and international drug experts condemned Thaksin's war on drugs. These international actors suggested instead to focus on "supply reduction strategies." Together with other US-based human rights organizations such as the Human Rights Watch, transnational activist networks urged the Thaksin-led to government to "focus on its own military and police, many of whose members allegedly profit greatly from facilitating the smuggling chain from Burma" (Adams 2003, 1). Even prominent public intellectuals 
in Bangkok voiced their opinions against Thaksin's localized version of the war on terror. Specifically, Surapol Nitikraipoj, an influential Thai legal scholar, criticized how Thaksin's wars were demonstrative of an authoritarian-style leadership: "The country is just too big to be governed by a lone individual or 36 people"(Asian Tribune 2003). In addition, the organizations of rehabilitated drugs users, many of whom benefitted from USAID-funded programs in the 1990s, critically spoke against the war on drugs.

In sum, Thaksin's version of the war on terror was carried out amidst widespread discourses of opposition both from international and domestic actors, including the US State Department. The overarching theme of such oppositional political discourses against Thaksin pertained to the anti-human rights character of the counter-insurgency operations. Most of these actors exhorted that increased state repression after 9/11 was indeed a regress from all the human rights reforms that gained traction in the 1990s. Thus, Somchai Homlaor, a long-time human rights advocate in Thailand, rightly observed that "in many provinces, there are death squads roaming around killing drug dealers," and because of that "the rule of law and democracy could disappear overnight" (Human Rights Watch 2004a, 3). Even recovering drug addicts expressed their fears of Thaksin's repressive policies. For instance, the 26-year-old Odd Thanunchai from Chiang Mai lamented that "Why do you have to kill people? It's better to help drug users find ways to change their behavior instead of killing them. There are not enough graves to bury us all." (Human Rights Watch 2004a, 1). Critics of the Thai government's war on drugs underscored the long-term impact of these human rights abuses to the democratic reforms that were carried out in the 1990s, and they referred to the long-term impacts of the Thai government's counterterror efforts. While the Thai government emphasized the need to sacrifice human lives for the sake of longterm peace and order, Thaksin's critics focused on human rights deterioration as a form of political regression from the reforms in the 1990s.

Thaksin's policy discourses that linked illegal drugs with international terrorism sought to legitimize the increased counter-insurgency operations. The local policy discourses in Bangkok clearly suggested that "Thaksin defined unrest in the borderland (Muslim-majority areas in southern provinces) as a product of underworld collusion (illegal drug traffickers)" (Askew 2007, 9). As a victim himself of death threats of drug kingpins, who were more supportive of the political opposition, Thaksin and his allies persistently portrayed illegal "drug trade and smuggling is [are] linked to the financing of terrorist activities, creating a relationship between terrorists and drug groups operating out of southern Thailand" (Cheow 2003). Such a strategy increased the credibility of Thaksin's justification for receiving counterterror support from the US government.

Even though many Thais decried the human rights abuses during Thaksin's tenure, the majority of the population apparently believed that the illegal drugs problem had to be combatted using repressive measures. The preliminary surveys conducted by independent Bangkok-based opinion polling agencies revealed that "90 percent of the public supported the crackdown, even though 40 percent said they were afraid of being falsely accused, and 30 percent said they were afraid of being killed" (Mydans 2003). Similarly, a 2003 survey conducted by the Bangkok-based Assumption University academics found that $84.2 \%$ of people living in Bangkok wholeheartedly supported the war on drugs, yet "of those same people, 65.3 percent expressed their fear that corrupt police could frame-up innocent people" (Ilchmann 2003). It was likely that the apparently overwhelming public admission that illegal drug use constituted a national 
security problem made it easier for Thaksin to deflect criticisms levied against him by opposition politicians and human rights defenders (Cumming-Bruce 2004).

The Thaksin administration reframed and localized international counterterror discourses in ways that related them to the nuances of the Thailand's long-standing security situation. In particular, this section demonstrated how Thaksin and his allies linked international terrorism with long-standing internal security problems in Thailand such as the armed secessionist movement in the southern provinces as well as the illegal drugs problem. Because of such a careful reinterpretation of international counterterror discourses, the Thai government justified the influx of terror-oriented strategic support from the US government and secured some form of preliminary public support for increased state repression. The material consequences of such counterterror discourses will be discussed in the next section.

\section{Resource Allocation: US Counterterror Assistance and the Expansion of the Thai Armed Forces' Activities}

How did terror-oriented political discourses from the Bush and Thaksin administrations manifest in actual domestic policies and foreign aid programs? How did such changes in discourses transform the Thai state's security apparatus as well as the patterns of domestic repression? Essentially, the terror-oriented discourses and militaristic policy agenda of the Bush administration provided the impetus for Thaksin's government to channel unprecedented amount of domestic state resources (and foreign aid) and political support to the Thai armed forces and police agencies. These resources were necessary in order to widely implement the killings, torture, and enforced disappearances - all of which drove the proliferation of human rights abuses in Thailand after 2003.

Thus, there are two key patterns of how foreign aid and domestic state resources were used in post-9/11 Thailand. The first pattern refers to the wide administrative discretion granted by the Bush administration to Thaksin over the use of US counterterror aid, while the second pattern pertains to the process of how such external material resources and terror-oriented discourses had been utilized to serve the Thai government's own political goals.

After promoting political discourses that sought to justify Thailand's role in the war on terror, the Bush administration provided Thaksin's government enormous amounts of counterterror financial assistance and other forms of military assistance. The US government granted wide administrative discretion to the Thai government, particularly in identifying specific local threats that can be linked to international terrorism and in using such resources to design counterterror strategies that would efficiently eliminate or undermine such domestic problems. Notwithstanding all the counterterror-related abuses of the Thai armed forces since 2001, Bush "in a press conference before the Asia-Pacific Economic Cooperation meeting in Bangkok months after Hambali's arrest referred to Thai special branch counterterrorism chief General Tritos Ranaridhvichai as 'my hero' for his role in the sting operation" (Crispin 2008). This only showed how the US government was much more concerned with the compelling goal of the capturing of terror suspects, even if such an approach systematically undermined US commitment to push its partner countries for stronger human rights compliance. 
Such a discretion in the use of terror-oriented US aid was given in exchange for Thailand's contribution to the advancement of post-9/11 strategic interests of the US government. For instance, the Bush administration asked the Thai government to regularly cooperate with the US authorities in capturing key Al-Qaeda linked terror groups based in Southeast Asia. In particular, the White House asked Thaksin's government to regularly provide intelligence regarding the whereabouts of the key leaders of Al-Qaeda linked terror groups based in mainland Southeast Asia (The White House - Office of the Press Secretary 2003). Bush also asked Thaksin, towards the end of 2001, to allow the CIA to bring Al-Qaeda suspects from Thailand to the USA, to use Thai military bases for the wars in Iraq and Afghanistan, and for Thailand to participate in "Pentagon's new strategy of 'forward positioning', establishing sites where American forces can store equipment and from which they can come and go as needed" (Bonner 2003). Also, the White House compelled the Thaksin administration in persuading the leaders of other ASEAN member countries to engage in USA-led multilateral counterterror intelligence sharing and other forms of military training. One of the landmark initiatives between Bangkok and Washington was the Container Security Initiative, signed by Secretary of Homeland Security Tom Ridge and Foreign Affairs Minister Surakiart Sathirathai. The aim of that initiative was to protect commercial shipping against terrorists (The White House - Office of the Press Secretary 2003). In addition, the US government dramatically increased the number of training programs, whereby Thai police and military officers learned the latest and most advanced counterterror techniques. A large number of Thai military and police officers benefitted from various counterterror training and assistance programs of the US government through the International Military Education and Training (IMET) program, Foreign Military Financing program (FMF), and Foreign Military Sales (FMS), all of which had increased its program budget since 2001 (Lohman 2011, 3). In addition, Thailand's prominent foreign policy analyst Pasuk Phongpaichit enumerated what the Bush administration directly asked from Thailand in exchange for hefty sums of post-9/11 US aid (Phongpaichit 2004, 83): (1) for Bangkok not to surrender any Americans for crimes against humanity and (2) for the country to be a key strategic site for US military equipment and regional counterterror operations.

This shows that the Thaksin-led government had accrued a sense of legitimacy and substantial military resources in exchange for its counterterror assistance to the US government. This quid pro quo approach to USA-Thailand foreign relations became much more apparent in the post-9/11 period when Bangkok benefits from closer economic cooperation and counterterror assistance against southern Thai Islamic insurgents, in exchange for the use of Thailand's military facilities and political support for the USA-led war on terror (Chambers 2004, 476).

One of the most controversial post-9/11 bilateral security initiatives was the establishment in late 2001 of the USA-funded Counterterrorism Intelligence Center based in Bangkok (CTIC) (Crispin 2008). Around "20 CIA officials are attached to the unit, which has received between $\$ 10$ million and $\$ 15$ million in U.S. funding" since late 2001 for personnel and equipment expenses (Lopez and Crispin 2003). The CTIC enables efficient and reliable intelligence sharing among the US, Thai, and other Southeast Asian government authorities in pursuit of armed terrorists linked to Al-Qaeda. This made Thailand a regional hub for all major US intelligence operations, and it also boosted the level of access of the Thai armed forces to technologies and other counterterror equipment from 
the USA. In addition, as early as late 2001, the US military had been "training Task Force 399 , a combined force of army personnel and border police, to fight drug trafficking along borders" (The Nation - Thailand 2001; Chambers 2004). The 20 instructors from the US Special Forces 1st Group assisted and led the 200 Task Force 399 officers, most of which came from the Thai Special Forces and the Thai Border Patrol Police based in Mae Rim (Chiang Mai). As a leading historian of drug trafficking, Pierre Arnoud Chouvy asserted: "as it does elsewhere to support its global war on drugs and terror, the United States not only offered technical and financial aid to Thailand's counter-narcotics programme but also directly improved the drug interdiction capacity of the Thai military by providing it with military equipment" (Chouvy 2010, 112). The US government provided these military equipment to the Thai armed forces, including state-of-the-art surveillance technologies, combat equipment, Black Hawk helicopters, and night-vision goggles (Montlake 2002).

The Thaksin administration redirected such external resources towards the police and military establishments primarily for publicly stated reasons relating to domestic counter-insurgency. In contrast to the 1990s, when the Thai civilian government agencies received much of the US aid for non-militaristic programs, the post-9/11 Thai national security agencies became the largest recipients of the financial assistance from the Bush administration.

Thai security agents instantly subjected all types of political rebels (armed and unarmed), suspected criminals, and drug addicts to torture, killings, and other forms of repressive measures. Indeed, as Thaksin explicitly "instructed police and local officials that persons charged with drug offenses should be considered "security threats" and dealt with in a "ruthless" and "severe" manner," blatant disregard for the Thai state's human rights commitments became undeniable (Human Rights Watch 2004a, 1-3). The systematic identification, harassment, detainment, and eventual killing of drug suspects or 'dark influences' initially started with "blacklists" or "watch lists." Many pro-Thaksin provincial politicians entered the names of their local political enemies in such lists and implicated these targets as somehow involved in illegal drug trade and consumption even in the absence of credible evidence. The aim was not only to consolidate a given local politician's authority but also to strengthen the TRT party's political power at the national scale (Human Rights Watch 2004b). That process of systematic elimination of political enemies illustrated how terror-oriented US strategic support was not only limited to the conduct of military operations against armed Islamic rebel groups in the southern region. Instead, in view of Thaksin and his TRT party's strategic goals, the Thai armed forces used material resources, counterterror techniques, and political support from the Bush administration to efficiently conduct Thaksin's war on drugs. For example, using US military aid, Thaksin's government provided hefty amounts of financial incentives to lure police officers and military agents to kill as many suspected drug dealers as possible. Thus, for each methamphetamine tablet seized, Thai police officers were awarded around 3 Thai baht (USD 0.7).

By the end of 2003, Thaksin officially reported that the 2003 war on drugs and on "dark influences" was a "victory" and "presented cash awards to agencies and officials who had taken part in the campaign" (Human Rights Watch 2004a, 12). The reward ranged from 50,000 Thai Baht to 100,000 Thai baht (US \$1275 to \$2550) for each official "who had been injured in the course of combating the drug trade and children of those killed in the campaign" (Human Rights Watch 2004b, 29 Thailand, Not Enough). 
Police officers and state security agents, who turned in a "major drug dealer into government custody_ 'dead or alive' - received a bounty of one million baht (23,600 USD)" (Ilchmann 2003). Furthermore, in response to pressures from Thaksin, the Interior Minister of Thailand threatened local elected authorities and police officers that their political careers would be jeopardized if they fail to produce the intended results of Thaksin's administration. Thus, the Interior Ministry of Thailand also instructed provincial officials to make use of "blacklists" that enumerate names of individuals based on mere suspicion of involvement in illegal drugs - all of which would then be subjected to state-sanctioned killings (US Department of State 2003).

The dramatic restructuring of the Thai bureaucratic apparatus facilitated the concentration of power towards Thaksin. The goal was to efficiently facilitate inter-agency cooperation in the context of the war on drugs and counterterror operations. All agencies became directly accountable to Thaksin's executive office. The other goal was to make all the key leaders of Thailand's national security agencies to be politically accountable to Thaksin. Such a bureaucratic restructuring meant that "the so called retreat into the barracks in the 1990s apparently ended with the 'repoliticisation of the military' under Thaksin by promoting his relatives and allies" (Kocak and Kode 2014, 91).

Yet, what exactly happened during this large-scale bureaucratic restructuring initiative by Thaksin? The restructuring began in October 2002, when the new fiscal budgeting year commenced in the Thai fiscal calendar. During this time, two important laws were ratified, namely the Bureaucratic Restructuring and the National Administration Acts, "collectively billed as Thailand's biggest bureaucratic shakeup in more than a century" (Mutebi 2003, 107). Because of the extensive scale and the intended wide-reaching effects of this bureaucratic shake-up, Thaksin named such an initiative as a "big bang" bureaucratic streamlining (Painter 2006; Painter 2006, 39). Six new ministerial offices and several other departments were created, with many of the civil servant positions were filled by retired high-ranking military officers and active officers who had close relations with Thaksin. For instance, General Chaisit Shinawatra, Thaksin's cousin, was appointed as an army chief in 2003, while another close relative, General Uthai Shinawatra, became a permanent defense secretary. Many other former classmates and friends of Thaksin in the police academy were appointed in key ministerial agencies, which used to be led by an experienced civilian bureaucrat. In fact, Thaksin intervened "into the army's internal affairs by promoting his loyalists, two of whom were his own relatives, to key military posts" (McCargo and Pathmanand $2005,147)$. In addition, the appointment of Thaksin's brother-in-law to the muchcoveted position of assistant police chief, thereby bypassing 14 other more senior police leaders, demonstrated how lines of accountability within the state were suddenly redirected to Thaksin (McCargo and Pathmanand 2005, 229).

The proliferation of cronies in key government and military posts "undermined the professionalism and neutrality among Thai soldiers" (Chachavalpongpun 2011, 46). Thus, Thaksin did not only undermine the seniority norm of the armed forces by appointing his relatives and allies to top positions but "also aimed at bringing strategic units under his personal command" (Kocak and Kode 2014, 91). Thaksin gained a unique advantage in efficiently leading the military and police in the counterterror operations, thereby swiftly killing and harassing armed and unarmed political opponents of the TRT party. These examples of politicization of the military and police agencies showed that Thaksin "increased his scope for patronage politics and 
maneuvered his supporters into key government positions, perhaps to further his stated aim of ruling for four consecutive terms - 16 years" (Mutebi 2004, 107). As a result, the Thai state effectively became more militaristic and beholden to the political whims of the TRT party and Thaksin.

Thaksin's bureaucratic restructuring tactics likely gained traction because of the domestic political support from the Thai population, in addition to the counterterrororiented assistance of the US government. Domestically, Thaksin and his Thai Rak Thai party won the political support for expanded counterterror efforts against armed rebels and suspected criminals from various important sectors that are influential in the Thai polity. Specifically, Thaksin won the conditional support of the Thai monarchy. This was the case especially for King Bhumipol, who was quite disapproving of Thaksin's populist politics, but was still very much in favor of increased US support for counter-insurgency in the southern provinces.

By promising financial incentives to local politicians and police officers in exchange for support to the war on drugs, Thaksin secured the political loyalty of these important local political actors. Thaksin also launched his "war on drugs" and increased counter-insurgency operations against armed rebels with an overwhelming support from the broader Thai public. Because of the predominantly Buddhist majority that comprised the Thai population, a large segment of the Thai population tended to support sustained military operations in the Muslim rebel-infested Pattani region. Because of the long-standing problem on illegal drug trafficking, some substantial segments of the Thai population were inclined to believe that the Thai government had to take repressive measures against anybody involved in illegal drugs. That was likely the case despite the overwhelming numbers of extrajudicial killings and disappearances thereafter (Mydans 2003).

Thus, the influx of terror-oriented material resources from the USA to Thailand exhibited how "American advisers and Thai autocrats converged in their commitment to building a powerful police force that was mobile, lethal, and amplified with civilian auxiliaries" (McCoy 2009, 537). Although the expansion of the Thai security agencies was one of the core strategic goals publicly shared by American and Thai officials, Thaksin and his allies opportunistically and covertly used these increased armed capacities of the state to quell many forms of political opposition, including unarmed civilian dissidents.

\section{Conclusions: the USA-Led War on Terror and Domestic Politics}

Why did Thaksin and his political allies decide to target both armed Islamic rebels in the southern regions of Thailand and suspected drug users for extrajudicial killings? Why did the Thaksin-led government include suspected drug users and political opposition members, composed mostly of "unarmed civilians," as targets for violent repression? The influx of terror-oriented US strategic support-counterterror public diplomacy and material resources including military aid-to the Thai government reinforced Thaksin's preexisting motivations to consolidate his political rule and authority. Such an external support from a long-standing ally attempted to bolster Thaksin's legitimacy in the face of pervasive doubts among some crucial sectors of Bangkok's political elites. By joining the USA-led war on terror, Thaksin and his domestic political allies considered increased state repression as a powerful display of 
authority that would secure the support of Thailand's traditional elites, many of whom were keen on violently addressing the armed insurgency problem in southern Thailand and on curbing illegal drug use. These elites included the Thai monarchy and the "royalist elites, sections of the military and many middle-class Bangkokians" (Ünaldi 2014; Funston 2002). Bangkok-based elites were generally hostile to the populist politics of Thaksin and his TRT party that began in the late 1990s.

Yet, the transformative consequences to the human rights situation in Thailand constituted a larger pattern in post-9/11 global politics. Located within the AsiaPacific security complex, Thailand played a pivotal role in the post-9/11 US strategy that framed Southeast Asia as the "second front on the war on terror," with the Middle East as the first front (Gershman 2002; Tan 2003). Foreign policy elites within the USA and the Asia-Pacific region viewed at that time that post-9/11 transnational terrorism posed a grave threat to the long-established American economic and political interests in the region. Beyond Asia, the US government dramatically increased its counterterror and militaristic assistance to Pakistan, Colombia, and Uganda, among many others; many, if not all, of them experienced deterioration in their domestic human rights situation. As Jason Ralph argued in 2013, "there is nothing strange about the US being at war" in the context of the post-9/11 strategy, yet "the Bush administration's decision to wage war against a non-state transnational network was unusual" (Ralph 2013, 1). That unique feature of the Bush strategy pertains to the willingness to view the AlQaeda threat through the lens of an armed conflict instead of a domestic law and security enforcement issue. Such a strategy discursively paved the way for other US allies, including Thailand, to wage their own "wars" against non-state actors that those states arbitrarily deemed as domestic security threats.

In closing, the post-9/11 human rights crisis in Thailand under the Thaksin regime became the starting point of the current political turmoil in the country. Yet, contemporary public and scholarly discourses seem to overemphasize the internal political factors that paved the way towards democratic regress. The empirical analysis herein is admittedly preliminary, yet it suggests that international factors dynamically interacted with the domestic variables that resulted in transformative changes in post-9/11 Thai state-society relations. Particularly, the analysis shows the "Thaksinification" of the USA-led global war on terror, which refers to the process by which Thai Prime Minister Thaksin Shinawatra strategically localized US counterterror discourses and tactically mobilized external material resources towards a terror-oriented expansion of the Thai state. Such a policy strategy resulted in the substantial increase in state repression and the pervasiveness of state-led physical integrity rights abuses in Thailand. Prospective studies of domestic political changes in Southeast Asian politics need to look into transnational-local interactions of factors (Regilme 2014a, b) that jointly produce transformative political changes in many Global South states that remain vulnerable to external influences. Future studies about foreign aid's political consequences should look into how the larger transnational and regional discursive structures enable the overarching agenda and implementation patterns of foreign aid programs.

Acknowledgements I thank a large number of people who provided feedback and ideas during the early stages of my research agenda on foreign aid and human rights. I am especially thankful to Lora Anne Viola for 
her unwavering intellectual support and advice that improved this project. I also thank Susan D. Hyde, Ben Cashore, Thomas Risse, Julia Adams, Nuno Monteiro, Alexander Debs, Lionel Beehner, Curd Knupfer, James Parisot, Shirin Saedi, Michael Weintraub, Kai Thaler and Pavin Chachavalpongpun, among many others.

Funding This work was supported by the Käte Hamburger Fellowship at the Centre for Global Cooperation Research in Duisburg (German Federal Ministry for Education and Research/BMBF), the 2017 Summer Research Travel Support from the Institute for History of Leiden University, the Fox International Fellowship at the Macmillan Center for Area and International Studies at Yale University, and the DFG Excellence Initiative Funding from the German Federal and State Governments.

Open Access This article is distributed under the terms of the Creative Commons Attribution 4.0 International License (http://creativecommons.org/licenses/by/4.0/), which permits unrestricted use, distribution, and reproduction in any medium, provided you give appropriate credit to the original author(s) and the source, provide a link to the Creative Commons license, and indicate if changes were made.

\section{References}

Acharya, Amitav. 2003. "The Bush Doctrine and Asian Regional Order: the Perils and Pitfalls of Preemption." Asian Perspective 27 (4): 217-247.

Adams, Brad. 2003. "Thailand's Crackdown: Drug “War” Kills Democracy, Too.” Human Rights Quarterly. New York City. http:/www.hrw.org/news/2003/04/23/thailands-crackdown-drug-war-kills-democracytoo- 0 .

Asian Tribune. 2003. "Thai PM Defends Anti-Terrorism Decrees.” Asian Tribune. http://www.asiantribune. com/news/2003/08/15/thai-pm-defends-anti-terrorism-decrees.

Askew, Marc. 2007. Conspiracy, Politics, and a Disorderly Border: the Struggle to Comprehend Insurgency in Thailand's Deep South. Washington, DC: East-West Center.

Associated Press. (2001) Bush: War on Drugs Aids War on Terror. CBS News. Available at: https://www. cbsnews.com/news/bush-war-on-drugs-aids-war-on-terror/. (Accessed September 5, 2017).

Associated Press. 2003. "Bush Declares Thailand a Major Non-NATO Ally.” New Straits Times, October 20.

Bonner, Raymond. 2003. "2003 Bonner NYT Thailand Tiptoes in Step with the American Antiterror Effort." New York Times, June 8.

Brown, Stephen and Jörn Grävingholt. 2016 Security, Development, and the Securitization of Foreign Aid. In The Securitization of Foreign Aid, edited by Stephen Brown and Jörn Grävingholt. London: Palgrave.

Bush, George W. 2003. "President Discusses War on Terror in Thailand." US State Department. Washington, DC: US Department of State. http://2001-2009.state.gov/p/eap/rls/rm/2003/25352.htm.

Carnegie, Allison Sovey, and Nikolay Marinov. 2017. Foreign Aid, Human Rights, and Democracy Promotion: Evidence From a Natural Experiment. American Journal of Political Science: 1-13.

Chachavalpongpun, Pavin. 2011. "Thaksin, the Military, and Thailand's Protracted Political Crisis." In The Political Resugence of the Military in Southeast Asia, edited by Marcus Mietzner, 45-62. Abingdon, Oxford: Routledge.

Chambers, Paul. 2004. "U.S.-Thai Relations After 9/11: a New Era in Cooperation?." Contemporary Southeast Asia: a Journal of International and Strategic Affairs 26 (3): 460-479.

Cheesman, Nick. 2003. "Murder as Public Policy in Thailand." Asian Legal Resource Centre. Hong Kong. http:/www.article2.org/mainfile.php/0203/86/.

Cheow, Eric Teo Chu. 2003. "Terrorists Regroup in Southern Thailand." Asia Times Online. http://www. atimes.com/atimes/Southeast_Asia/EH19Ae05.html.

Choi, Seung-Whan, \& James, Patrick. 2017. Are US Foreign Policy Tools Effective in Improving Human Rights Conditions?. The Chinese Journal of International Politics, 10(3), 331-356.

Chouvy, Pierre-Arnaud. 2010. Opium: Uncovering the Politics of the Poppy. Cambridge: Harvard University Press.

Cingranelli, David L, and Thomas E Pasquarello. 1985. Human Rights Practices and the Distribution of U.S. Foreign Aid to Latin American Countries. American Journal of Political Science 29: 539-563.

Cingranelli, David, and David Richards. 1999. Respect for Human Rights After the End of the Cold War. Journal of Peace Research 36: 511-534. 
Connors, Michael K. 2011. "Ambivalent About Human Rights: Thai Democracy." In Human Rights in Asia, edited by Thomas Davis and Brian Galligan, 103-122. Cheltenham and Northampton: Edward Elgar.

Crispin, Shawn W. 2008. "US and Thailand: Allies in Torture." Asia Times Online. http://www.atimes. com/atimes/Southeast_Asia/JA25Ae01.html.

Cumming-Bruce, Nick. 2004. "Some Neighbors Fault Hard-Line Approach in Thailand's South : Thaksin and Unrest Stir Doubt in Region." The New York Times. New York City.

Dabhoiwala, Meryam. 2003. "A Chronology of Thailand's "War on Drugs"." Asian Human Rights Commission. Hong Kong. http://www.humanrights.asia/resources/journals-magazines/article2/0203/achronology-of-thailands-war-on-drugs.

Debusman, Bernd. 2011. Pakistan and Questions Over Foreign Aid. Reuters. Available at: http://blogs.reuters. com/bernddebusmann/2011/05/13/pakistan-and-questions-over-foreign-aid/. (Accessed July 29, 2014).

Demirel-Pegg, T., and J. Moskowitz. 2009. US Aid Allocation: the Nexus of Human Rights, Democracy, and Development. Journal of Peace Research 46 (2) 163-180. Available at: http://jpr.sagepub. com/cgi/doi/10.1177/0022343308100713.

Dube, Oeindrila, and Suresh Naidu. 2015. Bases, Bullets, and Ballots: The Effect of US Military Aid on Political Conflict in Colombia. The Journal of Politics 77: 249-267.

Funston, John. 2002. "Thailand: Thaksin Fever." Southeast Asian Affairs, July, 305-325.

Gershman, John. 2002. Is Southeast Asia the Second Front ? Foreign Affairs 81: 60-74.

Hafner-Burton, Emilie M. 2014. A Social Science of Human Rights. Journal of Peace Research 51: $273-286$.

Hamilton-Hart, Natasha. 2012. Hard Interests, Soft Illusions: Southeast Asia and American Power. Ithaca: Cornell University Press.

Human Rights Watch. 2004a. "Timeline of Thailand's War on Drugs.” (Human Rights Watch). New York City. http://www.hrw.org/legacy/english/docs/2004/07/07/thaila9014.htm.

Human Rights Watch. 2004b. Thailand: Not Enough Graves: the War on Drugs, HIV/AIDS, and Violation of Human Rights. 16: 1-58. Available at: http://www.hrw.org/reports/2004/thailand0704/thailand0704.pdf.

Ilchmann, Susanne. 2003. "Thousands Dead as a Result of Thailand's 'War on Drugs'." WSWS/International Committee of the Fourth International. https:/www.wsws.org/en/articles/2003/05/thai-m09.html.

Kocak, Deniz, and Johannes Kode. 2014. "Impediments to Security Sector Reform in Thailand." In Security Sector Reform in Southeast Asia, edited by Felix Heiduk. Basingstoke: Palgrave.

Kono, Daniel Yuichi, and Gabriella R Montinola. 2009. Does Foreign Aid Support Autocrats, Democrats, or Both? The Journal of Politics 71: 704-718.

Kuhonta, Erik Martinez, and Alex M Mutebi. 2006. "Thaksin Triumphant: the Implications of One-Party Dominance in Thailand." Asian Affairs: an American Review 33 (1). Heldref: 39-51. doi: https://doi. org/10.3200/AAFS.33.1.39-51.

Lai, Brian. 2003. Examining the Goals of US Foreign Assistance in the Post-Cold War Period, 1991-96. Journal of Peace Research 40: 103-128.

Lebovic, James H. 1988. National interests and US foreign aid: The Carter and Reagan years. Journal of Peace Research, 25(2), 115-135.

Lee, Hyun Ju. 2011. The Impact of U.S. Foreign Aid on Human Rights Conditions in Post-Cold War Era. Master of Public Administration Thesis. Iowa State University.

Lohman, Walter. 2011. "Reinvigorating the U.S.-Thailand Alliance." Washington DC. http://www.heritage. org/research/reports/2011/09/reinvigorating-the-u-s-thailand-alliance.

Lopez, Leslie, and Shawn W Crispin. 2003. "U.S. and Thai Agents Collaborate in Secret Cold-War-Style Alliance.” Wall Street Journal. http://online.wsj.com/article/SB106496138273373900.html.

McCargo, Duncan, and Ukrist Pathmanand. 2005. The Thaksinization of Thailand. Copenhagen: Nordic Institute of Asian Studies.

McCoy, Alfred. 2009. Policing America's Empire: the United States, the Philippines, and the Rise of the Surveillance State. Wisconsin-Madison: University of Wisconsin-Madison Press.

Meernik, James, Eric L Krueger, and Steven C. Poe. 1998. Testing Models of U.S. Foreign Policy: Foreign Aid During and After the Cold War. The Journal of Politics 60: 63-85.

Montlake, Simon. 2002. "Diplomatic Pitfalls Frustrate Thailand's Antidrug Fight." The Christian Science Monitor. http://www.csmonitor.com/2002/1203/p07s02-wosc.html/(page)/3.

Mutebi, Alex M. 2003. Thailand in 2002: Political Consolidation amid Economic Uncertainties. Asian Survey 43 (1):101-112.

Mutebi, Alex M. 2004. “Thailand in 2003: Riding High Again.” Asian Survey 44 (1): 78-86.

Mydans, Seth. 2003. "A Wave of Drug Killings Is Linked to Thai Police." The New York Times, April 8.

Office of the Narcotics Control Board, Justice Ministry of Thailand. 2003. "War on Drugs' Concept and Strategy." Office of the Narcotics Control Board Ministry of Justice, Thailand. Bangkok. http://www. ahrn.net/Evidence/ONCB\%20-\%20War\%20on\%20Drugs.pdf. 
Painter, Martin. 2006. "Thaksinisation or Managerialism? Reforming the Thai Bureaucracy." The Whitehead Journal of Diplomacy and International Relations 36 (1). Taylor \& Francis Group : 26-47.

Panaspornprasit, Chookiat. 2004. "Thailand: Politicized Thaksinization.” Southeast Asian Affairs.

Petras, James. 1997. Imperialism and NGOs in Latin America. Monthly Review 49: 10-27.

Phongpaichit, Pasuk. 2004. Thailand Under Thaksin: Another Malaysia? Working Paper 109. Murdoch.Edu. A $u$. Perth1-12: Asia Research Centre, Murdoch University.

Qian, Nancy. 2015. Making Progress on Foreign Aid. Annual Review of Economics 7: 277-308.

Ralph, Jason. 2013. America's War on Terror: The State of the 9/11 Exception From Bush to Obama. Oxford: Oxford University Press.

Regilme, Salvador Santino F Jr 2014a. "Bringing the Global Political Economy Back in: Neoliberalism, Globalization, and Democratic Consolidation.” International Studies Perspectives 15 (3): 277-296.

Regilme, Salvador Santino F Jr 2014b. “The Social Science of Human Rights: the Need for a 'Second Image' Reversed?." Third World Quarterly 35 (8): 1390-1405.

Regilme, Salvador Santino Fulo, Jr. 2016. Why Asia's Oldest Democracy Is Bound to Fail. Journal of Developing Societies 32: 220-245.

Risse, Thomas. 2000. "Let's Argue!": Communicative Action in World Politics. International Organization 54 (1): 1-39.

Robinson, William I. 1996. Promoting Polyarchy: Globalization, US Intervention, and Hegemony. Cambridge: Cambridge University Press.

Shinawatra, Thaksin. 2003. Prime Minister's OrderNo. 29/2546Re: the Fight to Overcome Narcotic Drugs.

Sikkink, Kathryn. 2004. Mixed Signals: U.S. Human Rights Policy and Latin America. Ithaca, New York: Cornell University Press.

Simon, Sheldon W. 2003. "U.S.-Southeast Asia Relations: Southeast Asia Solidifies Antiterrorism Support, Lobbies for Postwar Iraq Reconstruction.” Comparative Connections a Quarterly E-Journal on East Asian Bilateral Relations. http://csis.org/files/publication/0302qus_seasia.pdf.

Tan, Andrew. 2003. Southeast Asia as the "Second Front" in the War Against Terrorism: Evaluating the Threat and Responses. Terrorism and Political Violence 15: 112-138.

The Nation - Thailand. 2001. "Thailand and Terror: US Shift May Take Heat Off Narcotics." The Nation Thailand. Bangkok. http:/www.nationmultimedia.com/The\%20Region/THAILAND-AND-TERRORUS-shift-may-take-heat-off-nar-51288.html.

The Nation - Thailand. 2003. "Thaksin Sets Up 2 Panels to Monitor Drug War." The Nation - Thailand. Bangkok. http://www.nationmultimedia.com/home/Thaksin-sets-up-2-panels-to-monitor-drug-war74831.html.

The White House - Office of the Press Secretary. 2003. "Joint Statement Between the United States of America and the Kingdom of Thailand." George W. Bush Archives, the White House. Washington, DC. http://georgewbush-whitehouse.archives.gov/news/releases/2003/06/20030611-1.html.

US Department of State. 2003. "Thailand.” US Department of State. Washington DC. http://www.state. gov/j/drl/rls/hrrpt/2002/18265.htm.

Ünaldi, Serhat. 2014. "Thailand: a Coup, the Crown, and Two Middle Classes." The Diplomat. http://thediplomat.com/2014/05/thailand-a-coup-the-crown-and-two-middle-classes/.

Wendt, Alexander. 1992. Anarchy Is What States Make of It: the Social Construction of Power Politics. International Organization 46: 391-425.

Wendt, Alexander. 1998. On Constitution and Causation in International Relations. Review of International Studies 24: 101-118. 